International Journal of Child, Youth and Family Studies (2013) 1: 54-71

\title{
UNDERSTANDING RISK AND PROTECTIVE FACTORS ASSOCIATED WITH CRIMINAL INVOLVEMENT IN A MULTICULTURAL SOCIETY
}

\author{
Hieu V. Ngo, Marian J. Rossiter, and Cam Stewart
}

\begin{abstract}
This study examined risk and protective factors associated with the criminal involvement of some members of the ethnocultural community. Results from ten focus groups comprised of diverse ethnocultural community members, law enforcement personnel, and service providers in four centres in Alberta revealed multiple, complex criminological risk factors related to home country experience, acculturation, strains in community interactions, socioeconomic disparity, negative media influence, and interaction with the criminal justice system. They also highlighted a number of protective factors that have prevented criminal involvement of ethnocultural community members, including family support, the strengths of ethnocultural communities, community engagement and civic participation, and access to social services. Insights from the focus groups served as the basis for a theoretical discussion and recommendations for crime prevention in a multicultural society.
\end{abstract}

Key Words: crime, risk factors, protective factors, ethnocultural, immigrants, visible minorities

Acknowledgement: This research was made possible by support from the Centre for Criminology and Justice Research, Mount Royal University. We wish to thank the ethnocultural community members, law enforcement personnel, and service providers who participated in the focus groups in the four centres. We appreciate the research assistance of the following Justice Studies students at Mount Royal University: Chris Abtosway, Brandon Pollon, Veronica Rosito, and Vi Tran.

Hieu V. Ngo, Ph.D. (the Corresponding Author) is Assistant Professor in the Faculty of Social Work, University of Calgary, 2500 University Drive NW, Calgary, Alberta, Canada, T2N 1N4. Email: $\underline{\text { hngo@ucalgary.ca }}$

Marian J. Rossiter, Ph.D. is Associate Professor in the Department of Educational Psychology, University of Alberta, 6-102 Education North, Edmonton, Alberta, Canada, T6G 2G5.

E-mail: marian.rossiter@ualberta.ca

Cam Stewart, M.A. is a part-time Instructor in the Department of Justice Studies, Mount Royal University, T154, 4825 Mount Royal Gate SW, Calgary Alberta, Canada, T3E 6K6.

E-mail: cgstewart@mtroyal.ca 
International Journal of Child, Youth and Family Studies (2013) 1: 54-71

Communities across Alberta have become increasingly diverse in terms of their racial, ethnic, religious, and linguistic backgrounds. Census data from 2006 show that foreign-born residents and visible minorities make up $16.2 \%$ and $13.9 \%$ respectively of the province's population (Statistics Canada, 2007a, 2008). This diversity enriches Alberta economically, politically, socially, and culturally.

Overall, residents of the province continue to have a strong sense of safety (see Alberta Crime Reduction and Safe Communities Task Force, 2007) congruent with declines in property and violent crime rates, as well as in severity of crime (Dauvergne \& Turner, 2010). However, in recent years, perceptions of criminal involvement of ethnocultural community members have risen, despite lack of evidence to support these fears (see Rassel, 2006). Unfortunately, the lack of public crime statistics related to immigration status, race, and ethnicity has seriously impeded research efforts to inform the public about the prevalence, patterns, and changes with respect to the criminal involvement of individuals from the various ethnocultural groups. Drawing upon the analysis of 10 focus groups comprised of diverse ethnocultural community members, law enforcement personnel, and service providers in four centres in Alberta, this article examines criminological risk and protective factors that are specific to ethnocultural communities.

\section{Background}

\section{Changing Demographics}

Alberta has the fourth highest rate of immigration of all the provinces in Canada; almost 11.6\% (32,642) of all immigrants to Canada settled in Alberta in 2010 (Citizenship and Immigration Canada, 2011). According to Statistics Canada (2007b), between 2000 and 2009, immigrants from Asia made up more than half of all newcomers to Alberta (70.1\%), followed by those from Europe (12.1\%), Africa (9.2\%), the United States (4.4\%), and the Caribbean and Central and South America (3.7\%). These patterns were in sharp contrast to those prior to 1961 when $90.5 \%$ of all newcomers arrived from Europe. Accordingly, the visible minority population has increased; data from Statistics Canada (2008) reveals that of those who immigrated to Alberta between 2000 and 2006, 75\% were of visible minority background, the largest groups being Chinese (26.5\%), South Asian (22.9\%), Filipino (11.2\%), African (10.4\%), Southeast Asian (6.3\%), Latin American (6.0\%), and Arab (5.8\%). Almost one-fifth of residents had a native language other than English or French, and almost one-tenth of the population reported that they spoke non-official languages at home (Statistics Canada, 2007a). Projections indicate that this trend toward increasing diversity will accelerate as the province continues to rely on immigration to meet workforce demands (see Statistics Canada, 2010; Bélanger et al., 2005).

\section{Overview of Social, Political, and Economic Realities}

Ethnocultural community members are underrepresented in social, political, and economic spheres in Canada. Socially, their rates of participation in activities and groups such as sports, hobbies, and community organizations are low (Statistics Canada, 2003a). They face barriers in accessing language training, housing, and health care (Ng, Wilkins, Gendron, \& Berthelot, 2005; Schellenberg \& Maheux, 2007), and are underrepresented in senior leadership 
International Journal of Child, Youth and Family Studies (2013) 1: 54-71

positions in organizations (McBride-King \& Benimahdu, 2004). Many ethnocultural members have experienced social marginalization, racism, and discrimination (Khanlou, Koh, \& Mill, 2008; Reitz \& Banerjee, 2007; Statistics Canada, 2003a), and resultant mental health issues (Davies \& Stevenson, 2006; Zayas, 2001).

Economically, immigrants’ participation in the labour market has been hindered by a lack of recognition of foreign credentials; furthermore, although twice as many immigrants as Canadian-born residents have a university education, immigrant unemployment is higher during the first 10 years of residence (7.3\% and 4.9\%, respectively; Zietsma, 2007), and immigrants earn significantly less than Canadian-born residents (Corak, 2008). Only 42\% are employed in their occupation of choice (Statistics Canada, 2005); a greater proportion work in the sales, service, and manufacturing sectors than Canadian-born residents (Cheung, 2007; Statistics Canada, 2003b). Second generation Canadians from immigrant families achieve higher education and earnings, but ethnocultural background plays a large role in their success. For instance, offspring of Chinese and Indian immigrants achieve higher levels of education than their counterparts from a Portuguese or African heritage (Abada, Hou, \& Ram, 2008; Abada \& Tenkorang, 2009; Simmons \& Plaza, 1998), and second generation visible minorities tend to have higher unemployment and lower earnings (Aydemir, Chen, \& Corak, 2009; Palameta, 2007).

In the political sphere, immigrant communities have a potentially strong influence as political parties increasingly appeal to the "ethnic vote", but they are less likely to cast a ballot during their first 10 years in Canada (Statistics Canada, 2003a). Visible minority Canadians vote less frequently than non-visible minorities (Reitz \& Banerjee, 2007), and are underrepresented in all levels of government (Black \& Hicks, 2006a, 2006b).

\section{Criminal Involvement of Ethnocultural Community Members}

In Canada, data related to crime, immigration status, race, and ethnicity are not generally available to the public, resulting in a lack of reliable information on diversity and crime to educate the public or inform policies and services. Annual reports from the federal correctional system, which is responsible for only a small fraction of all offenders with aggregate sentences of two years or more, provide some statistics in the form of annual reports. In 2009, almost twothirds of offenders in federal prisons were Caucasian (65\%); of the remainder, 18\% were Aboriginal, 8\% Black, 5\% Asian, 1\% Hispanic, and 3\% other/unknown (Public Safety and Emergency Preparedness Portfolio Corrections Statistics Committee, 2010). Incarceration rates for Aboriginals and Blacks compared with their proportional representation in Canadian society were almost three times higher than the national rates. Immigration status is not directly related to criminal involvement, but racial background is tied to gang membership; youth from Black, Hispanic, and Aboriginal backgrounds are more likely than others to become gang members (Wortley \& Tanner, 2006). Violent delinquency is more common among second generation youth than among those who were born in Canada or immigrated after five years of age (McMullen, 2009).

The findings of the limited Canadian studies on criminal involvement of ethnocultural community members are congruent with those from various studies from the United States. Firstgeneration immigrants are less frequently involved than native-born residents in violent crime, 
International Journal of Child, Youth and Family Studies (2013) 1: 54-71

homicide, and incarceration (Sampson, Morenoff, \& Raudenbush, 2005). Rates of incarceration increase, however, with length of residence in the U.S.A. and are particularly high amongst school dropouts (Rumbault, Gonzales, Komaie, Morgan, \& Tafoya-Estrada, 2006). Morenoff and Astor (2006) document the increased involvement in violent crime of second- and thirdgeneration children of immigrants, and of first-generation immigrants who arrived at six years of age or younger and have fewer language barriers than their older counterparts.

\section{Method}

\section{Focus Group}

The research team used the focus group approach for this study. Ten focus group interviews were organized in four centres in Alberta, involving a total of 70 representatives of ethnocultural communities, service providers, and law enforcement personnel (see Table 1). In City A, four focus groups were conducted, two for ethnocultural communities and two for service provider and law enforcement representatives. In each of the smaller centres, ethnocultural representatives formed one focus group, and law enforcement and service providers made up a second. The structured, audiotaped focus groups lasted from one to three hours. The research team transcribed and used the qualitative softwares, Atlas.ti and NVivo, to code and identify key themes, concepts, and relationships among the categories.

\section{Table 1. Focus group participants}

\begin{tabular}{lllll}
\hline City & $\begin{array}{l}\text { Number of focus } \\
\text { groups }\end{array}$ & $\begin{array}{l}\text { Ethnocultural } \\
\text { community } \\
\text { members }\end{array}$ & Service providers & $\begin{array}{l}\text { Law enforcement } \\
\text { personnel }\end{array}$ \\
\hline A & 4 & 16 & 10 & 8 \\
B & 2 & 7 & 5 & 1 \\
C & 2 & 2 & 7 & 1 \\
D & 2 & 4 & 7 & 2 \\
Total & 10 & 29 & 29 & 12 \\
\hline
\end{tabular}

\section{Participants}

A total of 70 individuals from diverse ethnocultural communities, the law enforcement sector, and service agencies participated in the ten focus groups. The 29 ethnocultural community representatives (12 women, 17 men) were (a) of African, Asian, South Asian, Middle Eastern, or Hispanic descent; (b) 18 years or older; (c) residents of Alberta for a minimum of 6 months; and (d) able to participate in discussions in English. Their average length of residence in Alberta was 7 years. All 12 law enforcement personnel and 29 service providers (17 women, 24 men) who participated in the focus group discussions had at least six months' experience working directly with ethnocultural communities in Alberta. 
International Journal of Child, Youth and Family Studies (2013) 1: 54-71

\section{Limitations of the Study}

The study had several limitations. Since it was based on the perceptions and opinions of the participants, it is possible that not all aspects of the involvement of ethnocultural community members in crime were accurate and free of bias. The short time frame in which this research was conducted did not allow adequate outreach activities to ensure full diversity of ethnocultural groups in the four communities. With respect to the group process, as is often the case with focus groups, some participants might have been more vocal than others in the discussions.

\section{Results}

\section{Risk Factors}

There was a general consensus among stakeholders that there are multiple, complex risk factors that have led some ethnocultural community members to commit crime. As a service provider pointed out, "It is schwack of issues. It is like peeling an onion.” Stakeholders identified a range of risk factors related to home country experience, changing family dynamics, community interaction, socioeconomic disparity, and interaction with the criminal justice system.

\section{Home country experience and pre-migration preparation}

Many respondents highlighted the exposure of some ethnocultural members to violence prior to their arrival in Canada. They pointed out the successive waves of refugees who had escaped violent wars in Bosnia, Sudan, and elsewhere. They felt that families who lost relatives to crime committed by members of another ethnic group and young men who were child soldiers in their countries of origin might suffer from post-traumatic stress disorder and be particularly vulnerable to violent crime. In addition, some participants in the ethnocultural focus groups felt unprepared for the struggles that they faced in Canada. They were told by the Embassies that their children would have free schooling, but they did not anticipate that their expectations would not be met, that they would live in poverty, and that crime might thereby become part of their life in Canada.

We come and we don't get the fulfillment of what we are expecting, you know. It causes us to be disconnected from the society. It seems that the only avenue they're put on is the avenue to commit crime. They're blocked off from every other opportunity, but the one to commit crime is wide open. (Ethnocultural community member)

\section{Family dynamics}

As articulated by a number of respondents, the experience of immigration and acculturation can cause family disruption and tension. Many workers who arrived in Canada alone have been challenged by the practical and emotional hurdles involved in bringing their families to Canada and taking care of them once they are reunited. Limited employment opportunities place stresses on workers and their families, which could create interpersonal tensions. Some ethnocultural families have struggled to accept changing gender roles. The 
International Journal of Child, Youth and Family Studies (2013) 1: 54-71

inability of some male partners or parents to adjust their expectations of their spouses or daughters could result in domestic violence. Many respondents echoed the belief that the varying levels of acculturation and conflicting life perspectives among family members weaken familial bonds and interactions, which in turn often results in inadequate parental guidance, the increased vulnerability of young people to negative influences, and experimentation with or sustained able engagement in unlawful activity. They were particularly concerned about the broad generation gap between first generation immigrants and their Canadian-born children.

I see that some of these children are having an identity crisis because they consider themselves as Canadians and their parents still hold onto the beliefs and the traditions and the culture. So that leads to a big gap, and it comes to a point that some of the kids are beyond parental control, because they just don't see eye to eye. (Ethnocultural community member)

Indeed, many respondents were concerned about erosion or underdevelopment of cultural identity among young ethnocultural members. They attributed this lack of an empowering cultural identity to rifts in family interactions, rejection of heritage culture, and internalization of negative cultural stereotypes.

I know these Muslim kids who have been in Canada for three or four years. They started to discover about drugs. I have parents calling kids into my office and said, "Look what I found in his room - marijuana." These young immigrants dive in headfirst. They haven't had the training in how to handle that kind of stuff. (Social services representative)

Respondents also observed role reversal in the parent-child relationship, where young people take on leadership roles to support their parents with language interpretation, understanding of new cultural norms, and, in some cases, financial assistance. They considered that these changes in power dynamics and sense of responsibility could set the stage for some young people to navigate the underworld and engage in illegal activities to support their families. Some respondents stated that young people also took advantage of their parents' limited English to mislead them with regard to their trouble with the law.

Stakeholders pointed out that the practical demands of life in Canada and financial responsibility for other family members in the home country have led many ethnocultural community members to overextend themselves with work. In their view, long working hours could hinder parents' ability to be actively involved in their children's lives, particularly in providing social opportunities and guidance to their children, especially in single parent households with limited financial capacity.

I am working with families that they are getting paid minimal wage and they are working constantly and so their children are unsupervised. Their children are pretty much alone to do a lot of things on their own. They tend to stray and seek approval from friends even if it's negative. (Social services representative)

Another respondent explained the cultural consequences of not having extended family in Canada: 
International Journal of Child, Youth and Family Studies (2013) 1: 54-71

In our culture, we can bring kids to our sisters and siblings, family, or relatives, leave them there and be assured they will be in good hands. Here, we have a different system and we don't have very much family support. (Ethnocultural community member)

Having to depend on Canadian caregivers in daycare facilities was reported to contribute to the acquisition of conflicting values, such as the development of independence at an early age, thus leading to cultural dissonance.

A few respondents observed that due to differing beliefs regarding acceptable parenting methods, many ethnocultural families have encountered serious trouble when parents use corporal punishment. One ethnocultural community member stated: “The kids have more authority than a parent because they report it to the school and now child services gets involved and then in two weeks the whole family collapses". They pointed out that, due to a fear of involvement of child protection services, some parents simply avoid disciplining their children altogether, which in turn can encourage young people to continue undesirable behaviours and, in some cases, move toward involvement in delinquent activity. Several respondents were concerned that parents with a criminal history have exposed or involved their children in illegal activity, particularly in drug-related crime.

\section{Community interaction}

According to stakeholders, complexities in the interactions between ethnocultural community members and the broader community have given rise to some criminological risk factors, including social isolation and lack of access to community support, cultural insularity, racism and discrimination, and absence of a sense of belonging. A lack of English proficiency and unfamiliarity with Canadian norms and customs have hindered the abilities of some ethnocultural members to cultivate and maintain cross-cultural social networks. Respondents noted a lack of knowledge of community resources and support among ethnocultural community members, as well as a limited access to existing services. They asserted that in some instances, ethnocultural community members neither identify with professional support nor trust the existing services in the larger community. One social services representative explained: "The families are afraid to send their kids to after-school programs because they think they will come back corrupt”. Respondents were quick to point out that many ethnocultural community members also do not receive or access social services and support in their cultural communities due to a lack of community capacity, or because, fearing social stigmatization, they choose not to access the existing support:

We don't usually learn about anger management or stress management. And we don't seek counseling because there is so much stigma there. It's just like you are going to go see a counselor because you are ill, you are crazy, in your mind. (Ethnocultural community member)

Many respondents indicated that racism and discrimination have alienated some ethnocultural community members. They shared incidents of racism and acknowledged the invisible cultural divides in their communities. Some respondents perceived the cultural insularity in some ethnocultural communities as a hindrance to crime prevention: 
International Journal of Child, Youth and Family Studies (2013) 1: 54-71

Often you can say you can take the person out of the country, but you cannot take the country out of the person. So what you find is that they have the bond, the trust, they have built upon themselves within their own communities. They literally shelter themselves, and, good or bad, they stand by it. So the challenge is actually being able to go in, going back to the trust, and how do you break in? How do you get them to buy in and how do you get them to engage? (Law enforcement officer)

Furthermore, stakeholders were concerned that many ethnocultural members, especially young people, do not have access to positive role models and are not involved in community and civic activities. They also identified exposure to negative media influences, notably in video games, television shows, or violent content on the Internet as a risk factor for criminal involvement:

Black Ops - it's all about killing and it's really bloody scenes and it really influences. Many young people play it almost every day, like they're addicted. They love that kind of experience, so they probably want to experience it in life. (Ethnocultural community member)

\section{Inequitable socioeconomic realities}

Stakeholders attributed the criminal involvement of some members to inequitable socioeconomic realities facing ethnocultural populations. They observed that many immigrants have limited access to employment opportunities and well-paid positions due to a lack of recognition by employers of foreign credentials and experience or, for some ethnocultural community members, due to a lack of English language skills and/or limited access to education and training. They contended that disenchantment with their economic prospects in Canada, compounded by financial responsibilities to extended families in their home country, could make profitable illegal activity an appealing option for some ethnocultural members.

There is money to be made [illegally], so why not get a good part of that? As opposed to working at Lakeside [Packers], getting up early and wrecking your body. What also leads some people to get involved in criminal activity is unemployment due to their limited English skills, [or] their credentials are not recognized here. They come home, they're frustrated, they're not living their purpose, they get angry with family members. (Social services representative)

Several respondents were concerned that not only do many ethnocultural community members not have their fair share of employment opportunities, but their children also lack access to responsive education and services. Stakeholders were concerned about: the practice of age-appropriate placement in schools that put young people with little prior education in high grade levels without adequate specialized educational and social support; the lack of support for both children and youth to develop English language proficiency; and an overall lack of advocacy for ethnocultural learners in the education system. A social services representative noted: "Young people don't have advocates for them at all, so it's easy for them just to jump on the other side, where it's easy to be accepted into a gang”.

A few respondents argued that discriminatory practices and limited socioeconomic and educational opportunities have perpetuated a sense of disconnection and marginalization among 
International Journal of Child, Youth and Family Studies (2013) 1: 54-71

some ethnocultural members. They observed that after some time many immigrants have become disillusioned:

You come to Canada because of the opportunity for your dream and your kids to have a better life, compared to where you came from. But when you come to the end, and this is the end of it, you become hopeless. You don't know what to do. You become isolated, confused. You just don't care. (Ethnocultural community member)

Furthermore, respondents identified poverty as a major risk factor for becoming involved in crime. They pointed out that those newcomers who bring money with them spend it on housing and utilities within the first few months and then become destitute. They also noted that some low income families have relied on subsidized housing by the government, and in some cases, members of one ethnic community are housed in the same complex to create social cohesion in the community, but they end up living in a ghetto. Several respondents observed that after the financial support from the federal government ends, the income of some immigrant families may decrease, and criminal activity may become more common in the neighbourhood. They also argued that homelessness is a stressor that can lead to intentional criminal acts by some ethnocultural members, who then find refuge in jail. A few respondents were critical of the refugee transportation loan which created a great financial burden on newcomers and pushed some refugees toward criminal involvement. They pointed out that loans may amount to $\$ 10,000$ plus interest for families (with additional loans to children over the age of 18):

A lot of refugee families are working to repay the loan, and there were some cases that they decided, "Okay, we have a big family and we have a big loan to repay. We need to sacrifice by sending one or two children to the gang or to commit some crimes so that they can make money quickly and repay the loans”. (Ethnocultural member)

\section{Interaction with the criminal justice system}

In the justice arena, stakeholders observed that some ethnocultural community members lacked knowledge of Canadian law, which led to violations. Several respondents recounted incidents where newcomers struggled to understand complex legal language and procedures, as well as nuanced assumptions about law enforcement in Canada:

The barriers are things like language. The criminal justice system is confusing. Half of my job is trying to explain the process to youth or to parents because it's a very confusing system. If you have never been in the system before and don't know what's going on. (Social service representative)

To complicate matters, stakeholders pointed out that some ethnocultural community members came from countries where the laws regarding certain offences, such as domestic violence or drinking and driving, were not enforced. A few participants insisted that foreign-born residents may perceive the Canadian criminal justice system to be lenient, and thus do not find judicial sentencing a stern deterrent to criminal involvement:

[Gang activity] is a high-risk business in itself, but you know, in Canada there is no death sentence, so who cares? And you can get bail easily, and it's so easy for people to be 
International Journal of Child, Youth and Family Studies (2013) 1: 54-71

offered, for example, the grow-op business. You can get a few hundred, tens of thousands of dollars within a month or so, so why not? It's so easy. (Ethnocultural community member)

Some ethnocultural community members, however, disagreed. They felt that the criminal justice system does not take into account the lack of understanding of Canadian laws and that it fails to give newcomers a second chance:

Our system makes us criminals from day one because, for example, someone arrives in this country. Within one week, they don't know how the law functions here. And then he drives a car without maybe having a license one day and, some days, drink and drive, and the license is confiscated. That would affect him not to get a job, because a vehicle is very important here. And if he fails to get a job, the only activity could involve drugs. (Ethnocultural community member)

A few respondents saw contact with the correctional system itself as a risk of criminal involvement. They encountered young people who had learned from other inmates to become more skillful in their criminal activity:

Even getting caught and thrown in jail is a bit of a status symbol for some of these kids. They go in for a month, right, and then they come out better skilled. They actually receive a bit of respect from their peers, right? Because now they're a bad person - they've been in jail. (Youth worker)

\section{Protective Factors}

Focus group participants emphasized that, in spite of tremendous challenges, most ethnocultural community members are law-abiding citizens. They identified a number of effective factors that have prevented the criminal involvement of ethnocultural community members, including family support, the strengths of ethnocultural communities, community engagement and civic participation, and access to social services.

\section{Family support}

Stakeholders identified active parental involvement and effective parental guidance as key to crime prevention. They noted that many ethnocultural community members are familyoriented and enjoy strong bonds and support from immediate and extended family members. Several respondents observed that in healthy families, parents pay a great deal of attention to their children and provide them with guidance, structure, and plenty of opportunities for positive social development. They also pointed out that young people look up to other family members for life choices and inspiration.

My parents kept us very busy with sports and were very diligent with keeping us in our routine. They were on top of us for pretty much every minute of our day, with either sports or chores...He [father] would always sit down and he just literally just watched me and my brother do our homework until we were done. (Ethnocultural community member) 
International Journal of Child, Youth and Family Studies (2013) 1: 54-71

Family values, with emphases on family honour and family togetherness, were also seen by participants as protective factors. Respondents from Southeast Asian communities in particular explained that youth who committed delinquent acts brought collective shame on their family and their community. Expectations of good behaviour are impressed upon youth from the outset. Some respondents pointed out that the tradition of children living with their parents until marriage in some cultures can also served as a protective influence. Furthermore, respect for parents and an understanding of parental expectations help children and youth to think about the consequences of behaviour. A respondent stated that if parents do not pay attention to where their children go, what they do, or who they spend time with, their children may get into trouble. This individual felt that parental supervision helped to lower the risk of criminal involvement, although it created cultural conflict for youth who espoused the independence promoted by Canadian culture.

\section{Strengths of ethnocultural communities}

Respondents recognized that the close-knit nature of various ethnocultural communities and their strong communal values discouraged individuals from engaging in activity disapproved of by their communities, while, at the same time, enabling community leaders and members to stay abreast of challenges facing individuals and to provide them with timely support. Some respondents cited the availability of mentors and role models in ethnocultural communities as a strong deterrent to crime. They pointed out that an informal network of mentors and role models provides natural community support that is more readily understood and embraced by many ethnocultural community members.

If you have a problem, you have your aunty or eldest in the family come together. They talk to you, they solve the problem. You don't have to go to a counselor or someone that is not a relative. (Ethnocultural community member)

Many respondents from various ethnocultural communities asserted that religion provides a protective influence. In their view, religious institutions provide natural community gathering places where ethnocultural community members readily benefit from moral guidance and practical and psychosocial support for positive integration. They pointed out that many immigrant families from Middle Eastern or South Asian communities have accessed services through religious organizations. Some respondents believed that religious teaching serves to remind individuals of ethical choices and the consequences of their behaviour. Another ethnocultural respondent explained that members of his church had been very supportive: "It has been a blessing for us because they have become our friends, our family, and everything, like we used to have in our country. People who we share our problems, our worries".

\section{Broad community engagement and civic participation}

Respondents agreed that active participation in all aspects of Canadian life would mitigate the risk of ethnocultural community members committing crime. They particularly highlighted the importance of volunteerism in cultivating a commitment to the well-being of the community, in utilizing skills and potential in positive ways, and in creating meaning in one's life. They pointed out that at a practical level, participation in voluntary activities enables many immigrants 
International Journal of Child, Youth and Family Studies (2013) 1: 54-71

to improve their English and to gain Canadian experience, and thus to broaden their access to legitimate employment opportunities:

Volunteerism, especially for youth, will help deter them from doing crime. Some of these youth have good leadership and organizational skills. Volunteerism gives them new vocabulary and opportunities to show what they are good at. This empowers them. (Social services representative)

Some respondents shared the view that accessing positive community gathering places could deter criminal involvement. They observed that many communities have used community centres and public libraries as safe, open spaces to provide after-school activities for young people and opportunities for all community members to socialize and learn with others.

One of the things we do at the library is we have some interactive video games in the basement. We have the Friday afternoon after-school program for teens...And so you have a way to keep them engaged, to keep them involved. (Librarian)

Several participants also identified integrated residence as a factor mitigating social solitude and ghettoization, which can make some members vulnerable to recruitment from organized criminal groups. A social services representative from one centre took pride in the city's success in achieving proportionate distribution of ethnocultural members in all communities.

\section{Access to social services}

Respondents agreed that access to timely, effective social services steers some ethnocultural community members away from criminal activity. They recognized that in spite of funding restraints, agencies have managed to provide a wide range of integration services to immigrants, ranging from language and life skills training to after-school programs for youth and classes on parenting and Canadian law. They also noted the benefits of various organizations' efforts to hire staff from diverse cultural backgrounds, to provide culturally responsive services and serve as positive role models for young people.

There was an emphasis on availability of early prevention and after-school programs as a protective measure. Respondents explained that, through these programs, young people are involved in recreational activities and receive educational and social support. They recognized the importance of early prevention and intervention programs that provide outreach and support to disadvantaged, behaviourally challenging children and youth. A few service providers found that leadership programs for youth with a criminal history can prevent recidivism:

We have some programs for youth with some sort of leadership qualities to make them community ambassadors. When the kids are told, "You've been identified by someone in the community as a leader", and the kids say, "I just got out of jail and now you want me to be a leader", you know it just changes that whole perception of how they feel about themselves. (Social services representative) 
International Journal of Child, Youth and Family Studies (2013) 1: 54-71

\section{Discussion}

Drawing upon what was learned from the focus groups with ethnocultural community members, law enforcement personnel, and service providers in Southern Alberta, this study identified the multiple risk factors related to home country experience, family dynamics, community interaction, socioeconomic opportunities, and interactions with the justice system that have contributed to the criminal involvement of some ethnocultural community members. At the same time, it was pointed out that the various protective factors, including family support, strengths of ethnocultural communities, broad community engagement and civic participation, and access to services can mitigate the risk of unlawful activity. Our findings supported the World Health Organization's (2002) ecological framework for identifying risk factors associated with crime, which asserts that individuals are affected not only by their individual characteristics and experiences (e.g., mental health, prior victimization, and substance abuse), but also by their relationships (e.g., family violence, crime-involved friends), the community in which they live (e.g., transient, high-crime neighbourhoods), and society at large (e.g., socioeconomic disparity). The findings lent support to the assertion that no single factor predisposes a person to become involved in crime, and that the greater the exposure to risk and the greater the absence of protective factors, the more likely it is that an individual will commit a crime (Blum, McNeely, \& Nonnemaker, 2002; Farrington \& Welsh, 2007; The Institute for the Prevention of Crime, 2007). In addition, our findings located the risk and protective factors in the unique experiences of immigration and acculturation of ethnocultural members, and their complex interactions with Canadian institutions.

Theoretically, the findings of this study illuminated both functionalist and structuralist criminological perspectives. Echoing the functionalist focus on the behaviour of individuals during a period of social anomie (see Durkheim, 1897/1952), they brought attention to the difficulties experienced by some ethnocultural members in coping with pre-migration and resettlement challenges (e.g., pre-migration trauma, lack of knowledge about Canadian norms, limited English), and in adapting to changing roles and expectations (e.g., gender roles, generational gap). At the same time, they were congruent with the structuralist school of thought which links crime to economic, social, and political inequities (see Bonger, 1936; Quinney, 1970). Our findings provided ample evidence of ethnocultural members who have struggled to gain access to employment opportunities and been denied responsive education and services. They also raised questions about social exclusion and the racialization of poverty.

This study suggested an intricate interplay within the social construction of crime of individual capacity to achieve positive integration into Canadian society and the prevalent socioeconomic inequities facing many ethnoculutral members. Crime prevention strategies in the context of a multicultural society, thus, ought to be comprehensive, coordinated, and culturally responsive, and address the three levels of prevention (see Brantingham \& Faust, 1976): namely, primary prevention (the general public or environment); secondary prevention (those at risk of committing crime); and tertiary prevention (those at risk of re-offending).

At the primary level, prevention strategies can promote policies and programs that build social harmony and cohesion through cultural exchange and public education, address the continuum of resettlement (e.g., language and literacy training, cultural orientation) and integration (e.g., sustainable livelihood, citizenship education, civic participation) needs of 
International Journal of Child, Youth and Family Studies (2013) 1: 54-71

ethnocultural members, and strengthen access of ethnocultural members to culturally competent services in health, education, social services, and justice (see Canadian Council for Refugees, 1998; Cross, Bazron, Dennis, \& Isaacs, 1989; Ngo, 2008, 2009a). At the secondary level, prevention strategies can focus on the availability of and access to family-based, communitybased and school-based support by ethnocultural members most at risk of committing crime. There are opportunities for stakeholders in all sectors - including the various levels of government, education, social services, and business - to develop and/or strengthen programs and services to address the key issues identified in this study such as English language education, literacy support, employment training, domestic violence and conflict resolution, acculturative gaps, pre-migration trauma, housing, and sustainable employment. Community development initiatives can help mobilize and involve community members in collaborative efforts to improve the surroundings and conditions that are conducive to unlawful activity. Finally, for those ethnocultural members with a criminal history, tertiary prevention strategies can focus on their positive reintegration into the community. Former gang-involved ethnocultural members who have successfully reintegrated into their ethnocultural communities and broad Canadian society, for instance, identified strong family support and access to timely, coordinated support and services, employment and education opportunities, and mentorship as effective tertiary strategies (see Ngo, 2009b).

\section{Conclusion}

This study sheds light on the risk and protective factors affecting criminal involvement in a multicultural society. Our findings validated the risk and protective factors highlighted in the existing literature, notably individual characteristics, family dynamics, access to socioeconomic opportunities, and the importance of the community environment. Theoretically, the findings reinforced both the functionalist and structuralist perspectives on criminology. This study made a unique contribution in presenting the specific issues facing ethnocultural community members, such as pre-migration experiences, acculturative challenges, specific socioeconomic inequities as related to immigrant and/or visible minority status, and access to culturally responsive supports and services. Additionally, the study demonstrated that effective crime prevention in a multicultural society requires coordination and comprehensiveness, and must address the primary, secondary, and tertiary levels of prevention. 
International Journal of Child, Youth and Family Studies (2013) 1: 54-71

\section{References}

Abada, T., Hou, F., \& Ram, B. (2008). Group differences in educational attainment among the children of immigrants. Ottawa: Statistics Canada.

Abada, T., \& Tenkorang, E. Y. (2009). Pursuit of university education among the children of immigrants in Canada: The roles of parental human capital and social capital. Journal of Youth Studies, 12(2), 185-207.

Alberta Crime Reduction and Safe Communities Task Force. (2007). Building safe communities and reducing crime. Edmonton: Alberta Justice.

Aydemir, A., Chen, W.-H., \& Corak, M. (2009). Intergenerational earnings mobility among the children of Canadian immigrants. The Review of Economics and Statistics, 91(2), 377397.

Bélanger, A., Malenfant, É. C., Martel, L., Carrière, Y., Hicks, C., \& Row, G. (2005). Population projections of visible minority groups, Canada, provinces and regions 2001-2017. Ottawa, ON: Statistics Canada. Retrieved from http://www.statcan.gc.ca/pub/91-541x/91-541-x2005001-eng.pdf.

Black, J. H., \& Hicks, M. B. (2006a). Visible minorities and under-representation: The views of candidates. Electoral Insight, 8(2). Retrieved from http://www.elections.ca/res/eim/article_search/article.asp?id=145\&lang=e\&frmPageSize= $\underline{5}$.

Black, J. H., \& Hicks, M. B. (2006b). Visible minority candidates in the 2004 federal election. Canadian Parliamentary Review, 29(2), 26-31.

Blum, R. W., McNeely, C., \& Nonnemaker, J. (2002). Vulnerability, risk, and protection. Journal of Adolescent Health, 31(l), 28-39.

Bonger, W. (1936). An introduction to criminology. London: Methuen.

Brantingham, P. J., \& Faust, F. (1976). A conceptual mode of crime prevention. Crime and Delinquency, 22, 130-146.

Canadian Council for Refugees. (1998). Best settlement practices. Montréal: Author

Cheung, L. (2007). Racial status and employment outcomes. Ottawa: Canadian Labour Congress.

Citizenship and Immigrant Canada. (2011). Facts and figures: Immigration overview. Ottawa: Minister of Public Works and Government Services Canada. Retrieved from http://www.cic.gc.ca/english/resources/statistics/menu-fact.asp. 
International Journal of Child, Youth and Family Studies (2013) 1: 54-71

Corak, M. R. (2008). Immigration in the long run: The education and earnings mobility of second-generation Canadians. IRPP Choices, 14(13), 1-30.

Cross, T. L., Bazron, B. J., Dennis, K. W., \& Isaacs, M. R. (1989). Towards a culturally competent system of care. Washington, DC: Georgetown University Child Development Centre, Technical Assistance Centre.

Dauvergne, M., \& Turner, J. (2010). Police-reported crime statistics in Canada, 2009 (Publication 85-002-X). Juristat, 30(2). Ottawa: Statistics Canada. Retrieved from http://www.statcan.gc.ca/pub/85-002-x/2010002/article/11292-eng.htm.

Davies, G., \& Stevenson, H. C. (2006). Racial socialization experiences and symptoms of depression among Black youth. Journal of Child and Family Studies, 15(3), 293-307.

Durkheim, E. (1897/1952). Suicide. London: Routledge.

Farrington, D. P., \& Welsh, B. C. (2007). Saving children from a life of crime: Early risk factors and effective interventions. Oxford: Oxford University Press.

Institute for the Prevention of Crime. (2007). Building a safer Canada. Ottawa: University of Ottawa. Retrieved from http://www.sciencessociales.uottawa.ca/ipc/eng/recomm_net_working_group.asp

Khanlou, N., Koh, J. G., \& Mill, C. (2008). Cultural identity and experiences of prejudice and discrimination of Afghan and Iranian immigrant youth. International Journal of Mental Health and Addiction, 6(4), 494-513.

McBride-King, J. L., \& Benimahdu, P. (2004). Toward maximizing the talents of visible minorities: Potential, performance and organizational practice. Ottawa: Conference Board of Canada.

McMullen, K. (2009). Self-reported delinquency of immigrant youth, Toronto 2006. Ottawa: Statistics Canada. Retrieved from http://www.statcan.gc.ca/pub/81-004x/2008005/article/10799-eng.htm.

Morenoff, J. D., \& Astor, A. (2006). Immigration assimilation and crime. In R. Martinez \& A. Valenzuela (Eds.), Immigration and crime: Race, ethnicity and violence (pp. 36-63). New York: New York University Press.

Ng, E., Wilkins, R., Gendron, F., \& Berthelot, J.-M. (2005). Dynamics of immigrants' health in Canada: Evidence from the national population health survey. Ottawa: Statistics Canada. Retrieved from http://www.statcan.gc.ca/pub/82-618-m/82-618-m2005002-eng.htm.

Ngo, H. V. (2008). Cultural competence: A guide for organizational change. Calgary, AB: Department of Canadian Heritage, Western Region. 
International Journal of Child, Youth and Family Studies (2013) 1: 54-71

Ngo, V. H. (2009a). Patchwork, sidelining and marginalization: Services for immigrant youth. Journal of Immigrant \& Refugee Studies, 7, 82-100.

Ngo, V. H. (2009b). Unravelling identities and belonging: Criminal gang involvement of youth from immigrant families. Calgary, AB: Centre for Newcomers.

Palameta, B. (2007). Economic integration of immigrants' children. Perspectives on Labour and Income, 19(4), 31-42.

Public Safety and Emergency Preparedness Portfolio Corrections Statistics Committee. (2010). Corrections and conditional release statistical overview. Ottawa: Author. Retrieved from http://www.publicsafety.gc.ca/res/cor/rep/2010-ccrso-eng.aspx.

Quinney, R. A. (1970). The social reality of crime. Boston: Little Brown.

Rassel, J. V. (2006, March 13). Gang fears grow in City A: Poll says half of city expects more violence. City A Herald, p. A1.

Reitz, J. G., \& Banerjee, R. (2007). Racial inequality, social cohesion, and policy issues in Canada. In K. Banting, T. J. Courchene, \& F. L. Seidle (Eds.), Belonging? Diversity, recognition and shared citizenship in Canada (pp. 489-545). Montréal: Institute for Research on Public Policy.

Rumbault, R. G., Gonzales, R. G., Komaie, G., Morgan, C. V., \& Tafoya-Estrada, R. (2006). Immigration and incarceration: Patterns and predictors of imprisonment among first- and second-generation young adults. In R. Martinez, Jr. \& J. R. Valenzuela (Eds.), Immigration and crime: Race, ethnicity and violence (pp. 64-89). New York: New York University Press.

Sampson, R. J., Morenoff, J. D., \& Raudenbush, S. (2005). Social anatomy of racial and ethnic disparities in violence. American Journal of Public Health, 95(2), 224-232.

Schellenberg, G., \& Maheux, H. (2007). Immigrants' perspectives on their first four years in Canada: Highlights from three waves of the Longitudinal Survey of Immigrants to Canada. Ottawa: Statistics Canada. Retrieved from http://www.statcan.gc.ca/bsolc/olccel/olc-cel?catno=11-008-X20070009627\&lang=eng

Simmons, A., \& Plaza, D. (1998). Breaking through the glass ceiling: The pursuit of university training among African-Caribbean migrants and their children in Toronto. Canadian Ethnic Studies, 30(3), 99-120.

Statistics Canada. (2003a). Ethnic diversity survey: Portrait of a multicultural society. Ottawa: Author. Retrieved from http://www.statcan.gc.ca/pub/89-593-x/89-593-x2003001eng.pdf. 
International Journal of Child, Youth and Family Studies (2013) 1: 54-71

Statistics Canada. (2003b). Longitudinal survey of immigrants to Canada: Process, progress and prospects. Ottawa: Author. Retrieved from http://www.statcan.gc.ca/pub/89-611-x/89611-x2003001-eng.pdf.

Statistics Canada. (2005). Longitudinal survey of immigrants to Canada: Progress and challenges of new immigrants in the workforce. Ottawa: Author.

Retrieved from http://www.statcan.gc.ca/pub/89-615-x/89-615-x2005001-eng.pdf

Statistics Canada. (2007a). Community profiles, 2006 census. Ottawa: Author. Retrieved from http://www12.statcan.ca/census-recensement/2006/dp-pd/prof/92-591/index.cfm?Lang=.

Statistics Canada. (2007b). Immigration in Canada: A portrait of the foreign-born population, 2006 census. Ottawa: Author. Retrieved from http://www12.statcan.ca/censusrecensement/2006/as-sa/97-557/index-eng.cfm.

Statistics Canada. (2008). 2006 census of population. Ottawa: Author.

Statistics Canada. (2010). Population projections for Canada, provinces and territories 2009 to 2036. Ottawa: Author. Retrieved from http://www.statcan.gc.ca/pub/91-520-x/91-520x2010001-eng.pdf.

World Health Organization. (2002). World report on violence and health. Geneva: Author. Retrieved from http://www.who.int/violence_injury_prevention/index.html.

Wortley, S., \& Tanner, J. (2006). Immigration, social disadvantage and urban youth gangs: Results of a Toronto-area survey. Canadian Journal of Urban Research, 15(2), 18-37.

Zayas, L. H. (2001). Incorporating struggles with racism and ethnic identity in therapy with adolescents. Clinical Social Work Journal, 29(4), 361-373.

Zietsma, D. (2007). The Canadian immigrant labour market in 2006: First results from Canada's Labour Force Survey. Ottawa: Statistics Canada. Retrieved from http://www.statcan.gc.ca/pub/71-606-x/71-606-x2007001-eng.pdf 